\title{
AGGRESSION IN BELARUSIAN'S INCARCERATED ADULT MALE OFFENDERS
}

Fourmanov I.A.

Department of Psychology, Belarusian State University, Republic of Belarus

Published: XIX World Conference of the International Society of Research on Aggression. Storrs, Connecticut, USA, July 27-31, Storrs, 2010. - P.48-49.

This study examined differences in four types of Belarusian's incarcerated adult male offender by the Aggression Questionnaire (Buss and Perry, 1992). Index offences were as follows: murder $(n=60)$, violent offences (grievous bodily injury, robbery, $n=35$ ) sexual violent offences (rape, $n=65$ ) and non-violent offences (larceny, swindle, $\mathrm{n}=95$ ).

There was a significant main effect of group for total score of aggression in that offenders convicted of murder scored higher than offenders convicted for another offences $(\mathrm{p}<.005)$. Those convicted for murder offences showed significantly higher scores for physical aggression $(\mathrm{M}=35.3, \mathrm{SD}=11.8)$ than violent offences $(\mathrm{M}=30.2, \mathrm{SD}=12.3, \mathrm{p}<.05)$, sexual violent offences $(\mathrm{M}=30.5, \mathrm{SD}=12.8$, $\mathrm{p}<.034)$ and non-violent offences $(\mathrm{M}=27.7, \mathrm{SD}=10.9, \mathrm{p}<.001)$. Also there was a significant interaction for the verbal subscale: murderers $(\mathrm{M}=21.8, \mathrm{SD}=6.1)$ were more verbally aggressive than were violent offenders $(\mathrm{M}=18.7, \mathrm{SD}=6.7, \mathrm{p}<.025)$, sexual violent offenders $(\mathrm{M}=19.2, \mathrm{SD}=7.3, \mathrm{p}<.031)$ and non-violent offenders $(\mathrm{M}=$ 19.1, $\mathrm{SD}=6.1, \mathrm{p}<.009)$. The differences of scores for anger and hostility in all groups of offenders were statistically insignificant.

Correlations were calculating between the severity of an offence and the Buss-Perry Aggression Questionnaire scores. The severity of an offence was significantly correlated with the total score $(\mathrm{r}=0.19, \mathrm{p}<.003)$, physical $(\mathrm{r}=0.23$, $\mathrm{p}<.0001)$ and verbal $(\mathrm{r}=0.16, \mathrm{p}<0.014)$ aggression. No significant correlations were founding with the severity of an offence, anger and hostility. 